\title{
Relevant lessons learned from the earthquakes El Asnam, 10/10/1980 and Zemmouri, 05/21/2003 on the paraseismic prevention in Algeria
}

\author{
Yamina Ait-Meziane ${ }^{1}$, Rania Souici ${ }^{2}$ and Farah Lazzali ${ }^{3}$ \\ ${ }^{1}$ CGS, National Earthquake Engineering Research Center, Algiers, Algeria \\ ${ }^{2}$ USTHB, University of Science \& Technology Houari Boumediene, Algiers, Algeria \\ ${ }^{3}$ UMBB, M'Hamed Bougara Boumerdes University, Boumerdes, Algeria
}

\begin{abstract}
In the field of seismic risk prevention in Algeria, the earthquake of El Asnam, 10/10/1980 is the triggering event and that of Zemmouri 21/05/2003 the accelerating element of the policy already in place. These two major events have been rich in information, as they are among the most studied internationally. The approaches and the development of methods for seismic risk reduction are based largely on feedback. The fundamental goal of seismic risk reduction is to avoid loss of life, which is mainly due to the partial or total collapse of structures. Exploiting lessons learned from past earthquakes is reflected in code requirements for new projects and approaches to vulnerability estimation for existing structures. In this paper, we give a description of the characteristics of the two events. The analysis of pathologies observed and the impact on the Algerian seismic code is discussed.
\end{abstract}

\section{Introduction}

Historically, northern Algeria experienced several seismic events [1]. The two major earthquakes that have occurred in Algeria, El Asnam (1980) Ms=7.3 and Zemmouri (2003) $\mathrm{Mw}=6.8$. accounted 3.500 deaths and 60.000 housing units destroyed for El Asnam region, 2.278 deaths and approximately 15.000 buildings destroyed for Algiers-Boumerdes region that is dense urban zone. In urban areas, the casualties due to earthquakes are usually important and often, the deaths and injuries are caused by partial or total collapse of buildings [2]. The results of field investigations and statistical analyses show that a majority of the damaged buildings were masonry buildings and reinforced concrete frame buildings, in part those built without any consideration to the requirements of the seismic code. In the case of the Zemmouri earthquake two wilayates were severely shaken, Algiers whose housing stock is essentially old, and Boumerdes a relatively recent area. In terms of earthquake prevention, the area of El Asnam was classified as a zone B by the AS55, a regulation not adapted to the regional seismic context; The area of Alger-Boumerdes was classified as a zone with moderate seismicity (zone II) by the earthquakeresistant wich standardizes the diagnostic protocol.

\section{Expertise protocol}

Damage to buildings is closely related to several factors such as: building parameters, geological and geotechnical conditions, and to the severity of the seismic event. The results of the damage observed on the buildings during the two events were carried out using the same post seismic expertise by using the damage evaluation sheet related to buildings in the surveyed area (building address, building use, age, number of stories, soils rupture (fault, liquefaction, landslide and settlement), foundation type, resisting system type and observed damage on structural and non structural elements) is collected. This first phase of buildings investigation is generally carried out very quickly; its objective is to classify globally all buildings into one of the three categories shown in Table 1. The investigator must conclude by given immediate decision about measures to take for the building. Each category (color) corresponds to the damage state of the building and its functionality after the earthquake. Green category is attributed to buildings with very little damage, which can be reoccupied immediately after the earthquake. Orange category is attributed to buildings which need further study before it can be either occupied or condemned (to be repaired or demolished). Red category is attributed to buildings which should be demolished.

Table 1 Categories of building damage and damage degrees according to the EMS-98 scale

\begin{tabular}{llll}
\hline Category & Damage state & Damage & Description \\
\hline Green & Very little damage. Can & Degree 1 & $\begin{array}{l}\text { Negligible to slight damage } \\
\text { (no structural and slight non-structural damage) }\end{array}$ \\
& be reoccupied immediately & Degree 2 & $\begin{array}{l}\text { Moderate damage (slight structural and moderate } \\
\text { non-structural damage) }\end{array}$ \\
\hline
\end{tabular}




\begin{tabular}{|c|c|c|c|}
\hline \multirow[t]{2}{*}{ Orange } & $\begin{array}{l}\text { Needs further study before } \\
\text { it can be either }\end{array}$ & Degree 3 & $\begin{array}{l}\text { Substantial to heavy damage (moderate structural } \\
\text { and heavy non-structural damage) }\end{array}$ \\
\hline & Occupied or condemned & Degree 4 & $\begin{array}{l}\text { Very heavy damage (heavy structural and very } \\
\text { heavy non-structural damage) }\end{array}$ \\
\hline Red & $\begin{array}{l}\text { Condemned and should } \\
\text { be demolished }\end{array}$ & Degree 5 & Destruction (very heavy structural damage) \\
\hline
\end{tabular}

\section{Zemmouri, may 21st, 2003 earthquake}

The latest earthquake that affected Algeria and caused significant damage is the Zemmouri earthquake, on May 21st, 2003. At 19:44:19 local time, the Zemmouri earthquake struck the Algiers-Boumerdes region in northern Algeria, with a magnitude $\mathrm{Mw}=6.8$. Zemmouri is situated approximately $60 \mathrm{~km}$ east of the capital city Algiers. The location of the epicenter was at $36.90^{\circ} \mathrm{N}$ and $3.71^{\circ} \mathrm{E}$ determined by the U.S. Geological Survey (USGS). The Algerian Research Centre of Astronomy, Astrophysics, and Geophysics (CRAAG) has determined that the epicenter was at $36.91^{\circ} \mathrm{N}$ and $3.58^{\circ} \mathrm{E}$, and at a depth of 8 to $10 \mathrm{~km}$ on the coast line near the village of Zemmouri. The maximum acceleration of $0.58 \mathrm{~g}$ was recorded at Keddara at about $20 \mathrm{~km}$ west from the epicenter [3].

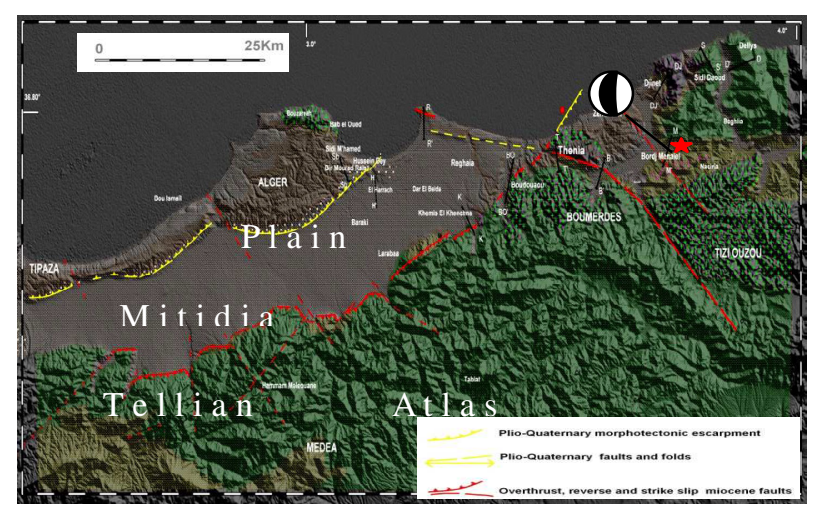

Fig.1.Characteristics of Zemmouri earthquake

The macroseismic study of Zemmouri earthquake [4] allowed establishing the isoseismic map reporting the spatial distribution of the earthquake effects in terms of maximum intensity (Fig. 2)

The earthquake of 2003 has affected the entire Boumerdes Wilaya and a part of capital Algiers. On June 1, the Government of Algeria reported that the earthquake killed 2.278, wounded 11.450 , and left approximately 200.000 people homeless. In addition, the earthquake interrupted medical services, water supply lines, electricity, and telecommunications in the region. Many Dairas and municipalities in Boumerdes and Algiers, are declared disaster zones by the central government decree of May 24, 2003.

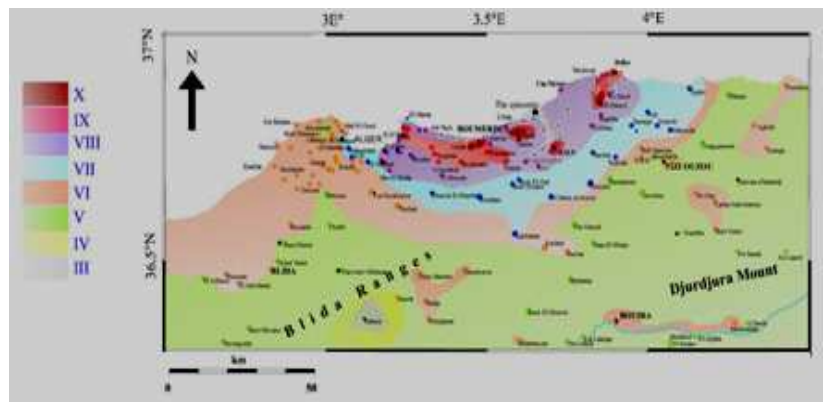

Fig.2. Isoseismal map of Zemmouri earthquake [4]

\subsection{Characteristics of buildings and observed damage}

In the survey mission following the 2003 earthquake, 728 engineers from the following public institutions and 626 other engineers and architects from private sectors were mobilized in the post-earthquake survey have been deployed throughout the 53 cities as declared disaster zones, in order to classify buildings into one of the three categories of damage.

The predominant category of buildings in the affected regions was the RC frame buildings [5], very few steel and wooden buildings mostly used for industrial purpose.

Based on the field investigations, the number of damaged buildings and the corresponding classification as of the 23 June 2003 are shown in Table 3, respectively [5]. A total of 181.658 buildings were investigated in the affected zones, with 66.383 in Boumerdes region and 105.287 in Algiers. In Boumerdes only, 7.465 buildings were destroyed [6].

Table 2 Buildings investigated and the corresponding classification

\begin{tabular}{cccc}
\hline Classification & Green & Orange & Red \\
\hline \multirow{2}{*}{ Algiers } & $\begin{array}{c}40147 \\
(44,56 \%)\end{array}$ & $\begin{array}{c}42452 \\
(7,12 \%)\end{array}$ & $\begin{array}{c}7497 \\
(8,32 \%)\end{array}$ \\
\hline \multirow{2}{*}{ Boumerdes } & $\begin{array}{c}39054 \\
(59 \%)\end{array}$ & $\begin{array}{c}19864 \\
(30 \%)\end{array}$ & $\begin{array}{c}7464 \\
(11,2 \%)\end{array}$ \\
\hline
\end{tabular}

Fig..3. shows the distribution of destroyed and condemned buildings (Red category) in Algiers - Boumerdes region following the Zemmouri earthquake. The High rate of destroyed buildings was recorded in the epicenter area and in the eastern part of Algiers city, dans le view quartier de Belouizdad.

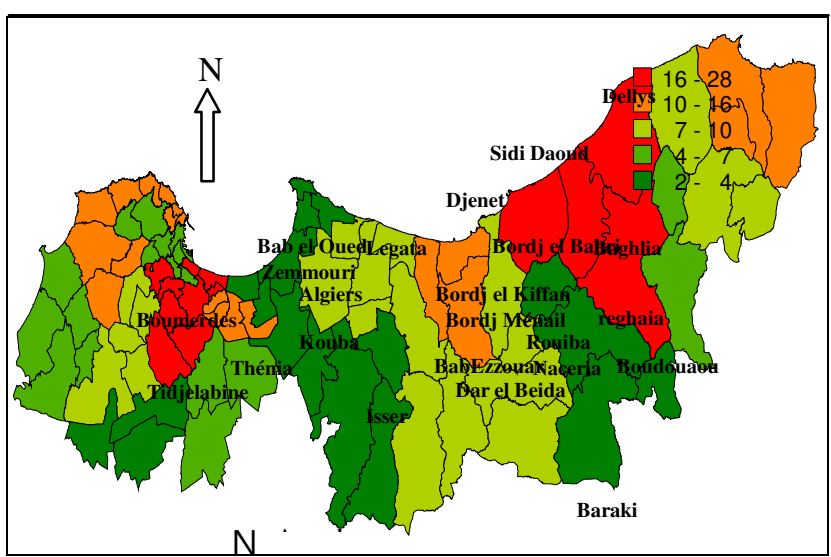

Fig.3. Distribution of destroyed and condemned buildings (Red category) in Algiers - Boumerdes region following the Zemmouri earthquake (rate in \%). 


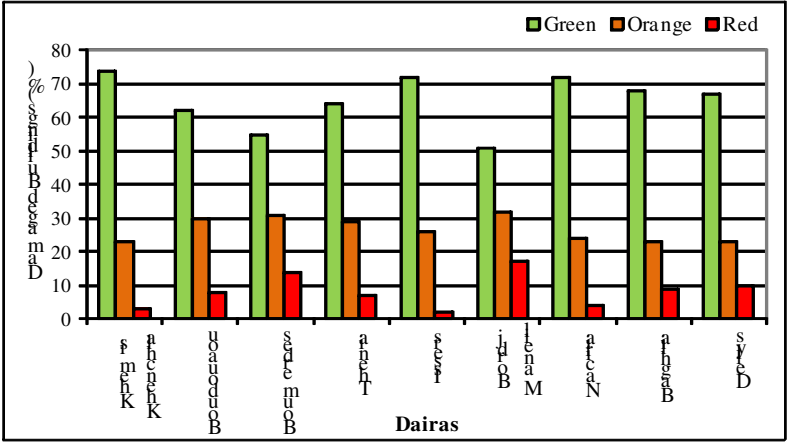

Fig.4. Damage distribution in the affected Daïras of Boumerdes
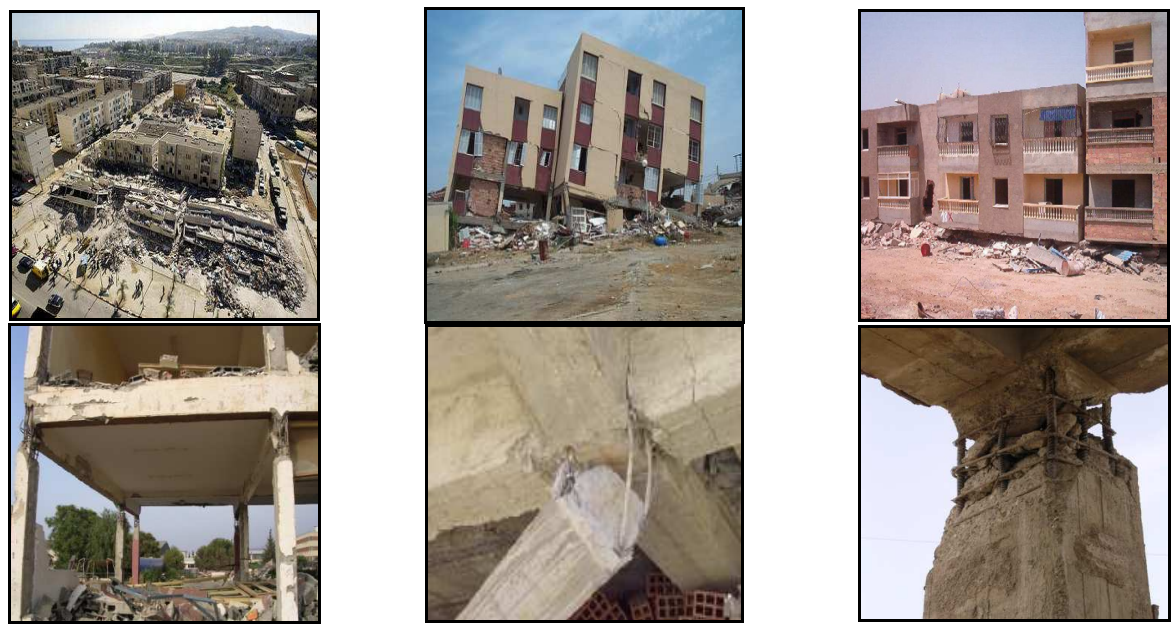

Fig.5. Photos showing damage in the affected areas in Boumerdes-Algiers region

\section{El Asnam, October 10th, 1980 earthquake}

El Asnam (known now by Chlef) earthquake was the first largest seismic event experienced in Algeria since the beginning of the 19 century. On October 10th, 1980 at 13:25:23 local time, El Asnam earthquake struck the Chelf region, at about $200 \mathrm{~km}$ west from the city of Algiers, with a magnitude $\mathrm{Ms}=7.3$ (USGS) (Fig. 6). The epicenter was located near the village of Beni-Rached which is $15 \mathrm{~km}$ north-east of El-Asnam at $36,143^{\circ} \mathrm{N}$ and $1,413^{\circ} \mathrm{E}$ at a depth of $10 \mathrm{~km}$. El Asnam earthquake was generated by a thrust fault striking $\mathrm{N} 60^{\circ} \mathrm{E}$ on 40 $\mathrm{km}$-long rupture zone dipping $45^{\circ}$ to NW [7]. The horizontal acceleration of the main shock was estimated in the epicenter area varying in the range of $0.25 \mathrm{~g}$ and $0.70 \mathrm{~g}$ [8].

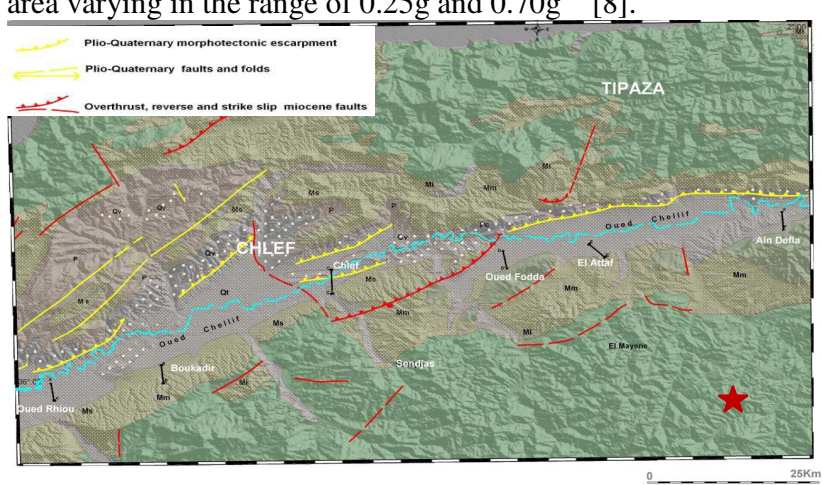

Fig.6. Characteristics of El Asnam earthquake of 10 October 1980

The macroseismic study of El Asnam earthquake [8-9], adapted from [10] seismic hazard study of Algeria, reported the spatial distribution of the earthquake effects in terms of maximum
Observed damage in Algiers-Boumerdes region can be summarized essentially as follow (Fig.5.): collapse of buildings; including total collapse, first soft story collapse, pancake collapse, kneecaps at the top of columns after bursting of masonry walls, collapse of unreinforced masonry buildings shear and compressive failure in columns, rotations at the ends of the columns with cracking and loss of concrete, diagonal cracks, out-of-plane failure with partial or total collapse of infill walls. intensity (Fig.7.), based on the damage level recorded in the affected zones. Intensities IX, X and XI (MM) were assigned to the epicenter area and the surrounding, containing sites where many constructions were destroyed or heavily damaged and where there was loss of life. The attenuation of intensity was quite rapid. Algiers, about $200 \mathrm{~km}$ east of the epicenter experienced between V and VI. Oran, about the same distance west of the epicenter also experienced similar intensity levels. The following cities were declared disaster zones after the earthquake are 06 Dairas El Asnam, Ain Defla, Tenes, Boukadir, El Attaf, Oued Rhiou corresponding to 28 municipalities.

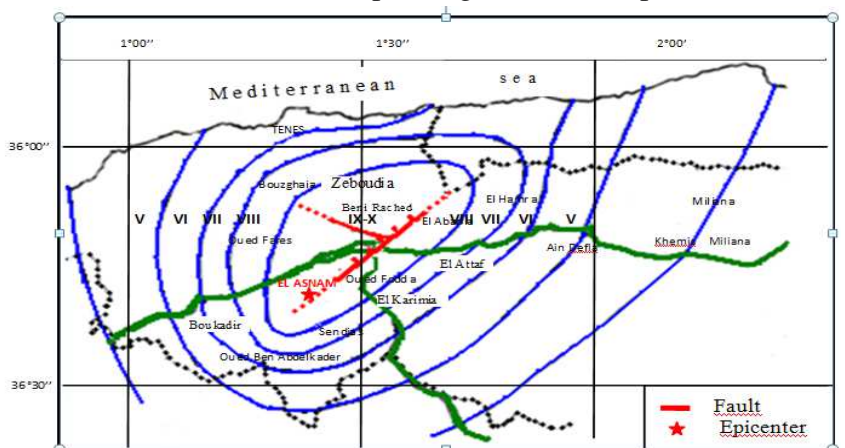

Fig.7. Isoseismal map of El Asnam earthquake (CTC 1981a, adapted from Mortgat and Shah,1978)

The buildings in category 1 are commonly unreinforced masonry buildings. These buildings performed no differently than has been observed in other past earthquakes. Substantial damage and partial collapse were common. A large number of stone and adobe houses that were either on the fault or within 50 meters of the fault collapsed in the village of Beni Rached. 
Unreinforced masonry houses and mosques surrounding El Asnam city, has shown great amount of damage. Many were severely damaged and some collapsed. Number of multistory buildings which had been reinforced after the 1954 earthquake with an externally applied concrete frame, performed very well with only non structural damage [8-9]. Buildings in category 2, built during the French period were dominantly concrete frame buildings with masonry infill walls. The performance of these buildings was poor with many total collapses such as the hospital, the schools and the hotels. These buildings appeared to have no rational system of lateral resistance. Collapse was most likely hastened by poor configuration and structural discontinuities [8-9]. In 1980, throughout the environs of El Asnam, large housing projects had been completed or were under construction. Building types varied from 1 story single family units to 5 story apartment buildings.

The distribution of damage to buildings in El Asnam and throughout the disaster area indicates that the most damaged buildings were dwelling and school buildings (Table 3 [8])

Table 3 Buildings investigated and corresponding classification

\begin{tabular}{cccc}
\hline $\begin{array}{c}\text { Classificat } \\
\text { ion }\end{array}$ & Green & $\begin{array}{c}\text { Orang } \\
\mathrm{e}\end{array}$ & Red \\
\hline $\begin{array}{c}\text { El Asnam } \\
\text { town }\end{array}$ & $\begin{array}{c}1720 \\
(33,41 \%)\end{array}$ & $\begin{array}{c}2162 \\
(42 \%)\end{array}$ & $\begin{array}{c}1200 \\
(23,31 \%)\end{array}$ \\
\hline Cities & 592 & 579 & 191 \\
surrounding & $(43,47 \%)$ & $(42,52 \%)$ & $(14,02 \%)$ \\
El Asnam \\
town
\end{tabular}
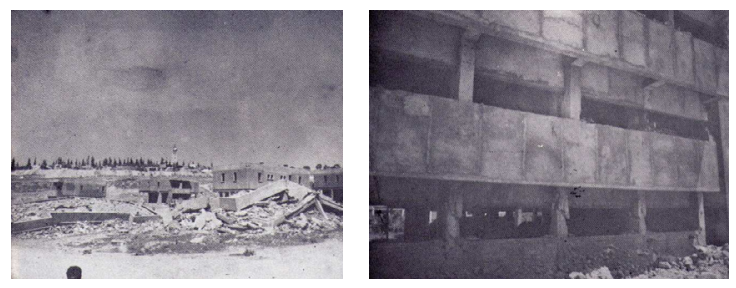

Fig.10. Damages observed in El Asnam earthquake

\section{Algerian Seismic codes}

The Algerian seismic code was revised in 1999 RPA99 [11], where major modifications were made such as the introduction of soil classification $S_{1}, S_{2}, S_{3}$ and $S_{4}$. The last version of the code was published in 2003 after the Zemmouri earthquake under the title: RPA99 version 2003 [12]. In all three versions before 2003, there were three seismic zones: Zone 0 (no seismicity) in the desert, Zone I (low seismicity), Zone II (moderate seismicity), and Zone III (high seismicity). Boumerdes and Algiers had always been classified as Zone II, with $0.15 \mathrm{~g}$ as the PGA for the design of apartment buildings.

In this last version of the code RPA99 Version 2003, the seismic zoning map was revised, including:

-Enlargement of zone III (enclosing before 2003 only El Asnam region). The new values of the seismic zoning factor A with 0.25
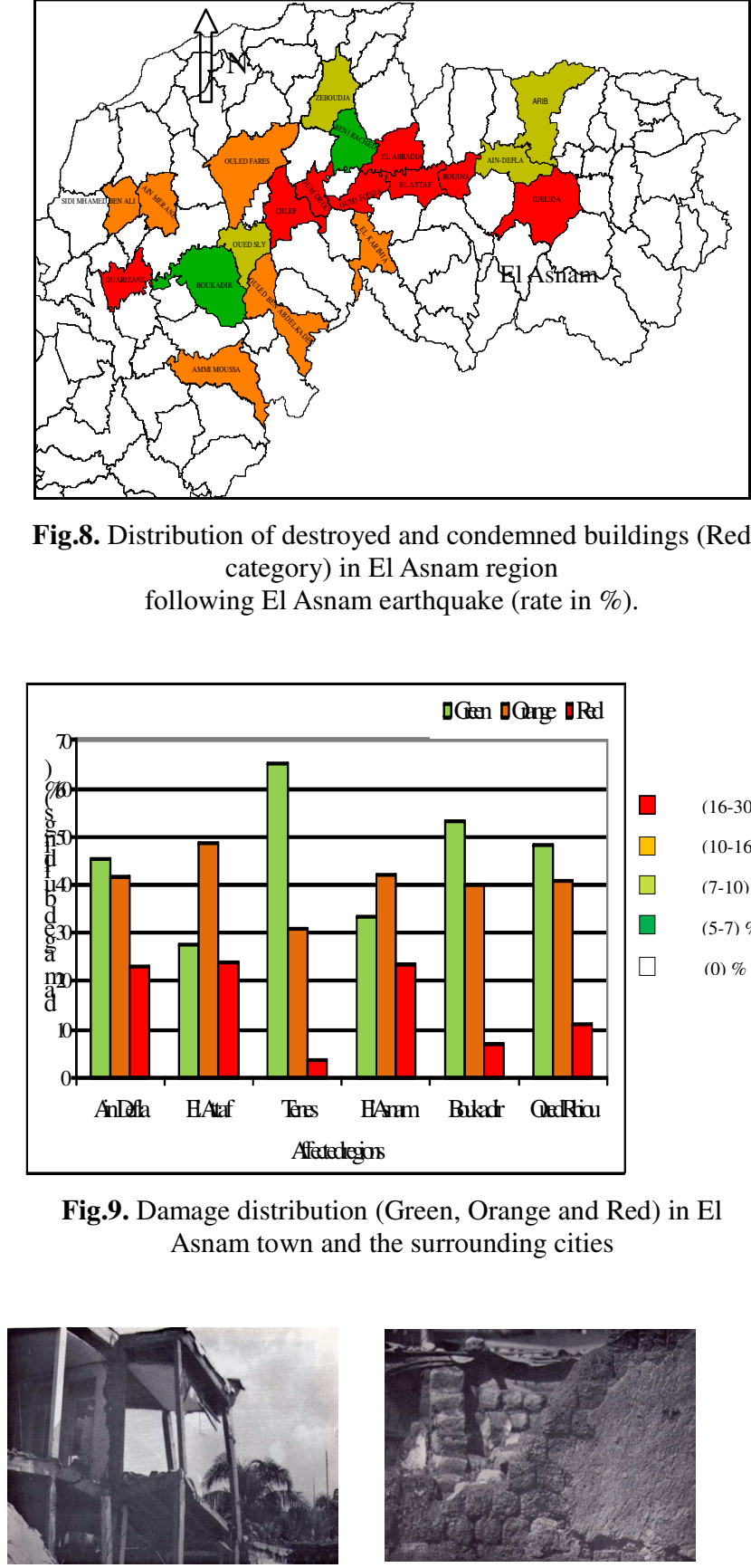

Fig.8. Distribution of destroyed and condemned buildings (Red category) in El Asnam region

following El Asnam earthquake (rate in \%).

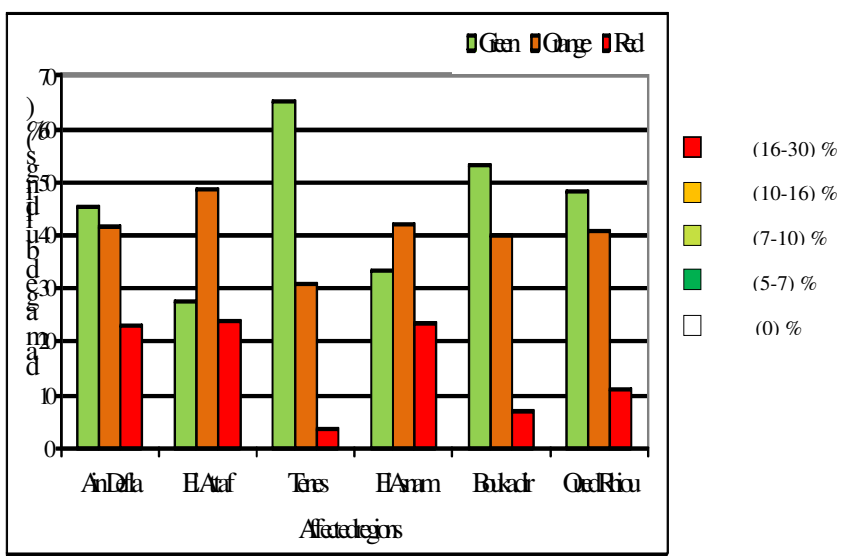

Fig.9. Damage distribution (Green, Orange and Red) in El Asnam town and the surrounding cities

$\mathrm{g}$ as the PGA for the design of apartment buildings.

-Establishment of two subzones of zone II; IIa and IIb, with two different levels of seismic severity.

-Prohibition of the RC frame system construction in zone III, and strengthening of RC frame structures under construction by addition of concrete walls.

-Strict and severe requirements in construction process.

-Application of the seismic design code became obligatory for private houses.

The Algerian seismic code RPA99 version 2003 defines a static lateral force procedure (simplified method) for determining the seismic actions on standard buildings. These actions do not apply to tall buildings, nuclear power stations, bridges, dams, retaining walls, tunnels and other important structures. The design base shear $\mathrm{V}$ is given by the following formula: 


$$
V=\frac{A D Q}{R} W
$$

Where; $\mathrm{A}$ is the seismic zoning factor, $\mathrm{D}$ is the dynamic amplification factor, function of site category $\left(S_{1}, S_{2}, S_{3}\right.$ and $\left.S_{4}\right)$, $\mathrm{Q}$ is the quality factor (penalty factor) and $\mathrm{R}$ is the behavior factor (17 constructive structural systems are defined in the code with different values of $\mathrm{R}$ ). The weight $\mathrm{W}$ of the building is calculated by assuming that the masses are concentrated at the floor levels. The value of $\mathrm{A}$ is given by the code, varying from 0.1 to 0.35 , depending of the seismic zone and the building use. The value of $\mathrm{D}$ is computed using the fundamental period and the damping. Q is depending of the resisting system organization and construction quality, varying from 1 to 1.35 . $\mathrm{R}$ is depending of the resisting system type, varying from 2 to 5 for RC buildings.

\section{Damage Analysis and discussions}

Globally, the analysis in term of damage level, shows that the collapsed and condemned buildings in Boumerdes and Algiers, following the Zemmouri earthquake, and in El Asnam, following El Asnam earthquake, were respectively; 11,2\%, $8,15 \%$ and $38 \%$ (Fig. 11). The most affected buildings typologies were the dwelling buildings (Fig.12.), due to their high number compared to schools, hospitals, administrative or commercial buildings. The numbers of dwelling buildings were respectively; 98\%, 95\% in Algiers and Boumerdes, and 69.75\% in El Asnam. In addition, the analysis shows that the number of buildings that suffered significant damage with a possibility of repair (Orange category) was important mainly in Algiers. The dwelling buildings in the affected zones of Algiers, classified in Orange category reached $50 \%$. This can be explained by the fact that buildings in Algiers are old and vulnerable [13-14]

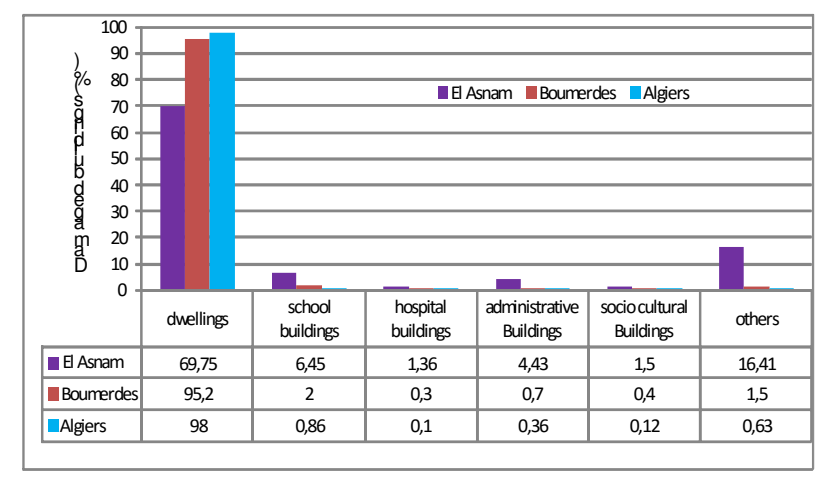

Fig.11. Damaged buildings by typologies in the affected zones

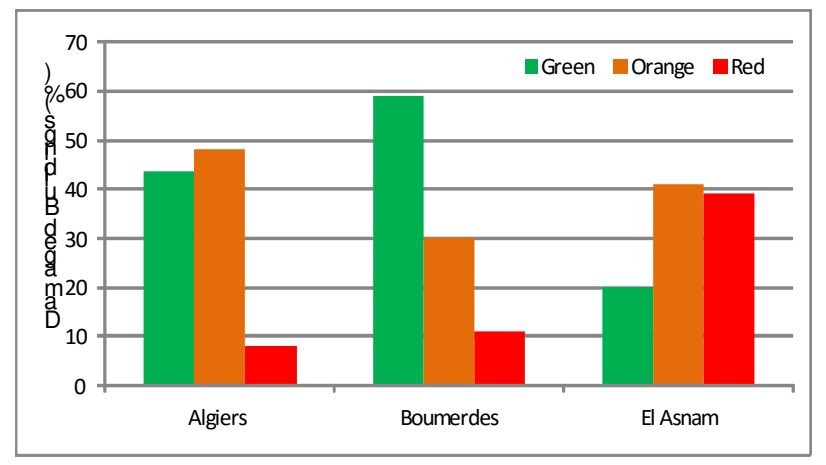

Fig.12. Damaged buildings by category (Green, Orange and Red) in Algiers and Boumerdes following Zemmouri earthquake and in El Asnam following Asnam earthquake

\section{Conclusions}

In this study, the observed damage distribution during these two strong earthquakes has been analyzed, expressing how buildings suffered severe damage and identifying the deficiencies of the structural systems. The study has also presented the major contributing factors to the observed damage distribution in Algiers-Boumerdes region after the 2003 earthquake and in El Asnam region after the 1980 earthquake, i.e., the structural characteristics and the sites conditions.

Globally, the analysis in term of damage level has shown that the highest rate of collapsed buildings following the two earthquakes was recorded in El Asnam, following El Asnam earthquake with $38 \%$. The most affected buildings typologies following the two events were the dwelling buildings. Among these building 50\% located in Algiers were classified in Orange category, corresponding to damage degrees 3 and 4 in the EMS 98 scale, due to the fact that the buildings in Algiers are old and vulnerable. The high rate of damage recorded in the affected zones confirmed the poor behavior of the RC frame system largely used in the region, due essentially to the inadequate sizing and reinforcing of columns and beams and to the bad materials and process quality.

The seismic hazard in Algeria was not sufficiently known and seismic code regulation did not exist before 1980. In all version of the Algerian seismic code published after 1981 and before the 2003 earthquake, the seismic hazard was included in terms of seismic zones and design acceleration. The resistance capacities mandated by the different versions of the seismic code did not differ significantly. The accelerations recorded in Zemmouri 2003 earthquake have confirmed the inadequate level of seismic hazard in the seismic code. Consequently, in the revised version of the seismic code RPA 99 version 2003, seismic zones have been modified and the PGA for the design buildings has been increased.

Decision-makers need adequate information on the expected intensity in the disaster that the cities will face in order to reduce seismic vulnerability.

\section{References}

1. (CRAAG) (1994), "Les séismes en Algérie de 1365 à 1992". Publication du Centre de Recherche en Astronomie, Astrophysique et Géophysique, Département: Etudes et Surveillance Sismique, ESS, C.R.A.A.G, Algiers.

2. Coburn, A. and Spence, R. (2002), "Earthquake Protection", 2nd edition. John Wiley \&Sons.Ltd., Chichester, England.

3. Earthquake Engineering Research Institute (EERI) (2003), "The Boumerdes, Algeria earthquake of May, 21, 2003", Report, pp. 57. Learning from Earthquakes Program, Oakland, CA.

4. Harbi, A, Maouche, S., Ousadou, F., Rouchiche, Y., Yelles-Chaouche, A., Merahi, M., Heddar, A., Nouar, O., Kherroubi, A., Beldjoudi, H., Ayadi, A., and Benouar, D. (2007), "Macroseismic Study of the Zemmouri Earthquake of 21 May 2003 (Mw 6.8, Algeria)", Earthquake Spectra, Volume 23, No. 2, 315-332.

5. Belazougui, M. (2008a), "Boumerdes Algeria earthquake of May 21, 2003: Damage analysis and behavior of beam-column reinforced concrete structures", 14th World Conference on Earthquake Engineering, 12-17, Beijing, China. 
6. Japanese Reconnaissance Team (2004), “Boumerdes earthquake, May 21, 2003", 144p.

7. Meghraoui, M., Maouche, S., Chemaa, B., Cakir, Z., Aoudia, A., Harbi, A., Alasset, P.J., Bouhadad, Y., Benhamouda, F. (2004) "Coastal uplift and thrust faulting associated with the $\left(M_{w}=6.8\right)$ Zemmouri (Algeria) earthquake of 21 May, 2003”, Geophys., Res. Let. V.31, 119605.

8. Technical Control of Construction (CTC) (1981b), "Règles parasismiques Algériennes, RPA81", Algiers.

9. Earthquake Engineering Research Institute (EERI) (1980), "El Asnam earthquake, Algeria, 10 ${ }^{\text {th }}$ October 1980", Report, 57. Learning from Earthquakes Program, Oakland, CA.

10. Mortgat, C.P. and Shah, H.C. (1978), "Seismic Hazard Analysis of Algeria"; Technical Report. The John A. Blume Earthquake Engineering Center, Department of Civil Engineering, Stanford University, Stanford, CA.

11. National Research Centre of Earthquake Engineering (CGS) (1999), "Règles parasismiques Algériennes, RPA99", Algiers.

12. National Research Centre of Earthquake Engineering (CGS) (2003), "Règles parasismiques Algériennes, RPA99 version 2003", Algiers.

13. Ait-Méziane, Y., Farsi, M. N. and Benouar, D. (2004), "Seismic vulnerability estimation of representative building in the Algiers district of Bab El Oued (Algeria)", European Earthquake Engineering, 1, pp. 27-36.

14. Lazzali, F. and Farsi, M.N., (2012), "Seismic vulnerability assessment of buildings in Algiers area", International Conference on Environmental and Civil Engineering, WASET, Issue 61, pp. 796-800, Dubai. 